\title{
Removal of Triton X-100 and SDS from Protein Solutions with Zeolite Y
}

\author{
Zoltan Blum ${ }^{\mathrm{a}}$ and Håkan Eriksson ${ }^{\mathrm{b}}$ \\ anorganic Chemistry 2, Chemical Center, University of Lund, P.O. Box 124, S-221 00 Lund, and 'Department of Biotechnology, \\ Chemical Centre, University of Lund, P.O. Box 124, S-221 00 Lund, Sweden
}

Zoltan, B. and Eriksson, H., 1990. Removal of Triton X-100 and SDS from Protein Solutions with Zeolite Y. - Acta Chem. Scand. 44: 531-532.

Detergents are commonly used in biochemistry. They are amphiphilic molecules containing a hydrophobic and a hydrophilic part. The hydrophilic part can be charged or uncharged and detergents often are characterized as being an-, cat- or non-ionic. In biochemistry detergents are mainly used for solubilizing cell membranes and protein aggregates.

Purification of membrane components and intracellular molecules is often carried out in presence of detergents. However, detergents may interfere with the purification method used. Thus ion-exchangers may bind anionic or cationic detergents and non-ionic detergents, that form large micelles, may cause an increased apparent molecular weight upon gel filtration.

The development of cDNA technology and the increased production of recombinant proteins, which often form intracellular protein aggregates, 'inclusion bodies,' has increased the demand for fast and large-scale purification methods of intracellularly formed proteins. So far, the most commonly used methods for the removal of detergents from protein solutions are dialysis, ion exchange chromatography and adsorption onto hydrophobic matrices. In this letter we describe the use of a hydrophobic zeolite as an adsorbing matrix for detergents.

Zeolites, framework aluminium silicates or tectosilicates, are characterized by their chemical composition and pore size. ${ }^{1}$ The chemical composition is conveniently expressed in terms of the $\mathrm{Si}: \mathrm{Al}$ ratio. High-silica zeolites carry less framework charge and are commonly referred to as hydrophobic; the opposite holds for high-alumina zeolites which are labelled hydrophilic. Pore sizes vary typically in the range 3-7.5 $\AA$ and the accessibility of the porous system is dimensionality dependent. Of the suitable zeolites, zeolite $\mathrm{Y}$, mordenite, and silicalite can be obtained essentially free from aluminium either through direct synthesis (silicalite) or by means of post-synthetic manipulations (mordenite, zeolite Y). Zeolite Y and mordenite have pore sizes in the upper range, 7.5 and $7.0 \AA$ respectively, while silicalite is a middle-range zeolite with $5.5 \AA$ pore size. The porous systems in zeolite $\mathrm{Y}$ and silicalite are readily available owing to the three-dimensional arrangement of the channels; mordenite is somewhat less efficient since the porous system is one-dimensional.

\section{Experimental}

Zeolites were added to phosphate-buffered saline (PBS, 10 $\mathrm{mM}$ phosphate, $150 \mathrm{mM} \mathrm{NaCl}, \mathrm{pH} \mathrm{7.4)} \mathrm{containing} 10 \mathrm{mg}$ $\mathrm{ml}^{-1}$ bovine serum albumin (BSA, Cohn fraction V, Sigma Chemicals Co., USA) and $10 \mathrm{mg} \mathrm{ml}^{-1}$ Triton X-100 (Merck, Darmstadt, FRG) or $10 \mathrm{mg} \mathrm{m}^{-1}$ sodium dodecyl sulfate, SDS (specially pure, BDH Chemicals Ltd., Poole, England). The suspensions were vortex mixed for $60 \mathrm{~s}$ and centrifuged for $10 \mathrm{~min}$ at $12,000 \times g$ before assaying of the detergent remaining in the supernatant. Zeolites were obtained from Tosoh Co., Japan and silica $\left(\mathrm{SiO}_{2} \cdot x \mathrm{H}_{2} \mathrm{O}\right)$ used in the control experiments was obtained from Merck, Darmstadt, FRG.

${ }^{3} \mathrm{H}$-Triton X-100 (NET-556 lot number 2481-229) used as a tracer was purchased from NEN Research Products, Boston, USA. Before the detergent was dissolved in PBS, ${ }^{3} \mathrm{H}$-labelled Triton X-100 was mixed with unlabelled Triton $\mathrm{X}-100$, dissolved in methanol and evaporated to dryness. This procedure reduced the amount of radioactivity by $30 \%$.

Table 1. Adsorption of detergents onto zeolites. ${ }^{a}$

\begin{tabular}{llrl}
\hline Zeolite & $\begin{array}{l}\text { Pore size } \\
\text { IA }\end{array}$ & Si:Al & $\begin{array}{l}\text { Triton X-100 remaining } \\
\text { in the supernatant (\%) }\end{array}$ \\
\hline Zeolite Y & 7.5 & $>1000$ & 0.7 \\
Silicalite & 5.5 & $>1000$ & 87 \\
Mordenite & 7.0 & 46 & 86
\end{tabular}

a Zeolites $\left(100 \mathrm{mg} \mathrm{ml}^{-1}\right)$ were added to a solution of $10 \mathrm{mg} \mathrm{ml}^{-1}$ Triton X-100 in PBS. After vortex mixing for $60 \mathrm{~s}$, the zeolites were pelleted by centrifugation and the detergent remaining in the supernatant was determined by adsorption at $276 \mathrm{~nm}$. 


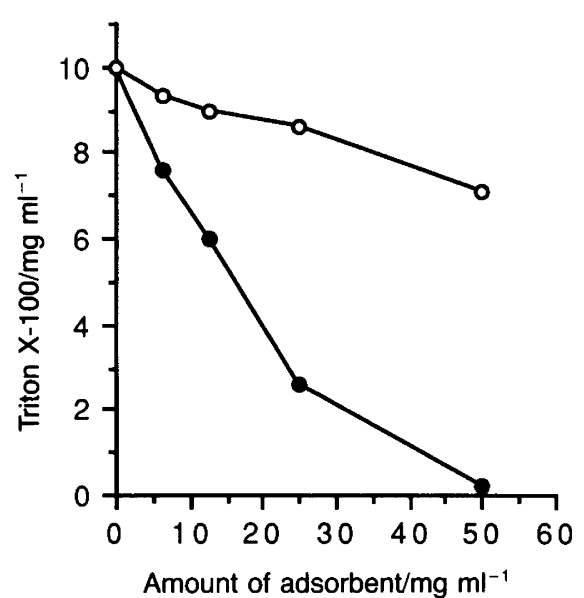

Fig. 1. Adsorption of Triton $\mathrm{X}-100$ onto zeolite $\mathrm{Y}(\Theta)$ and onto silica particles $(O)$.

Adsorption of Triton X-100 onto zeolite $Y$ and onto silica particles. Triton $\mathrm{X}-100\left(10 \mathrm{mg} \mathrm{ml}^{-1}\right)$, and ${ }^{3} \mathrm{H}$-labelled Triton $\mathrm{X}-100\left(1.4 \times 10^{6} \mathrm{dpm} \mathrm{ml}^{-1}\right)$ were dissolved in PBS $(10 \mathrm{mg}$ $\mathrm{ml}^{-1}$ BSA) as described above. Various amounts of zeolite $\mathrm{Y}$ or silica particles were added to the detergent solution and this was vortex mixed for $60 \mathrm{~s}$. The adsorbents were removed by centrifugation and $100 \mu$ l of the supernatants were counted in a $\beta$-counter.

\section{Result and discussion}

Zeolites are commonly used as adsorbers of low molecular weight substances. A recent proposition as to the mechanism of adsorption in zeolites in general, and especially in hydrophobic zeolites, is based on the geometry of the framework structure. ${ }^{2}$ In a hydrophobic zeolite carrying little or no framework charge, the adsorptive properties are described as a result of the focusing of the total van der Waals forces. ${ }^{3}$ The focusing efficiency is a consequence of the particular geometry involved and hence is different for different zeolites. In an attempt to find a zeolite that adsorbs detergents, three zeolites of known hydrophobic properties were examined (Table 1). The initial experiments were performed with an anionic detergent, sodium dodecyl sulfate (SDS), and a non-ionic detergent, Triton $\mathrm{X}-100$. Significant adsorption of both detergents was only obtained with zeolite $Y$.

Binding of ${ }^{3} \mathrm{H}$-labelled Triton $\mathrm{X}-100$ to zeolite $\mathrm{Y}$ and to silica particles is shown in Fig. 1. After the addition of 50 $\mathrm{mg} \mathrm{ml}^{-1}$ zeolite $\mathrm{Y}, 1.7 \%$ of the radioactivity remained in the supernatant. This gives a concentration of $0.27 \mathrm{mM}$ Triton X-100 which is close to its critical micelle concentration (cmc), 0.24 mM. Furthermore, no lysis of red blood cells could be obtained with Triton X-100 solutions treated with $50 \mathrm{mg} \mathrm{ml}^{-1}$ zeolite $\mathrm{Y}$, which is in agreement with a detergent concentration below its cmc. A concentration below $\mathrm{cmc}$ was also obtained when BSA was omitted from the detergent solution and the amount of detergent remaining after treatment with zeolite $\mathrm{Y}$ was assayed by absorption at $276 \mathrm{~nm}$. However, if the mixture of ${ }^{3} \mathrm{H}$-labelled and non-labelled Triton X-100 was not dissolved in methanol and evaporated to dryness before dissolution in PBS, $30 \%$ of the radioactivity remained in the supernatant after treatment with $50 \mathrm{mg} \mathrm{ml}^{-1}$ zeolite $\mathrm{Y}$. The manufacturer states their ${ }^{3} \mathrm{H}$-labelled Triton $\mathrm{X}-100$ to be $99 \%$ pure. We agree with the manufacturer after removal of the volatile radioactivity from the ${ }^{3} \mathrm{H}$-Triton $\mathrm{X}-100$ preparation.

Adsorption of Triton $\mathrm{X}-100$ to zeolite $\mathrm{Y}$ is achieved after vortex mixing for less than $60 \mathrm{~s}$. Compared with other hydrophobic matrices, such as BioBeads SM- $2,{ }^{4}$ the adsorption onto zeolite $\mathrm{Y}$ is much faster and indicates an adsorption mechanism based on direct binding of the detergent micelles.

A solution of $10 \mathrm{mg} \mathrm{ml}^{-1}$ SDS treated with $100 \mathrm{mg} \mathrm{ml}^{-1}$ zeolite $\mathrm{Y}$ showed no lysis of red blood cells. SDS is an anionic detergent and hence the adsorption of detergent to zeolite $\mathrm{Y}$ is independent of charge, instead the adsorption is dependent on the size of the hydrobic part of the detergent molecules. Removal of detergents from solutions by the use of zeolite $\mathrm{Y}^{5}$ is fast and efficient and should have numerous applications in biochemistry and biotechnology.

Acknowledgements. This project was supported by grants from The National Swedish Board for Technical Development.

\section{References}

1. Breck, D. W. Zeolite Molecular Sieves, Wiley, New York 1974.

2. Thomasson, R., Lidin, S. and Andersson, S. Angew. Chem., Int. Ed. Engl. 26 (1987) 1017.

3. Blum, Z., Lidin, S. and Thomasson, R. Solid State Chem. 74 (1988) 353.

4. Holloway, P. W. Anal. Biochem. 53 (1973) 304.

5. Swedish Patent Application 8902919-3.

Received December 19, 1989 